\title{
Historical account of venereal diseases in Mexico
}

\author{
Carlos J Conde-Glez, Ernesto Calderón, Luis Juárez-Figueroa,
} Mauricio Hernández-Avila,

\begin{abstract}
This paper reviews the history of sexually acquired diseases in Mexico. It is divided into four major chronological sections which discuss social attitudes and values, the development of services and of official policy, and historical epidemiology.
\end{abstract}

(Genitourin Med 1993;69:462-466)

PRE-CONQUEST PERIOD (1325-1521)

Legend melts into history in this period, when Mexico was inhabited by more than eighty distinct ethnographic groups, disconnected and with cultures less developed than those of the Aztec and Maya. The social structure was composed of a religious class, nobles, warriors and the general community. Male polygamy was only accepted among nobles, while warriors had access to groups of women who lived isolated from society, and who provided sexual services for them, especially on their return from combat. Within the family, women played a secondary role, and were responsible for the home, procreation and children's education. Adultery committed by a woman was punishable by death. ${ }^{1}$

Medicine was based on magical and supernatural ideas within these cultures, but, nevertheless, venereal diseases were recognised in both sexes, and especially in women who were considered "public". When these women experienced "fetid secretions" from their genitals or any type of visible lesion, they were segregated or forced to live outside of the town until cured. Urinary pain was treated in men and women with potions prepared from a variety of herbs and roots, and genital inflammation with plasters to the affected area. ${ }^{1}$

COLONIAL PERIOD (1521-1810)

The conquerors travelled from Spain following the coast from South to Northeast up to Veracruz, where they continued on to Tenochtitlan (now Mexico City). They immediately established feudal social relations, and put the entire female population at the disposal of their soldiers; women were obtained as gifts or through sales. As a consequence of abuse of the indigenous population, rules similar to those in use in the Spanish courts were introduced, and polygamy was eliminated. Nevertheless, soldiers and officials were permitted to have large numbers of servants. Prostitution was tolerated and came under the surveillance of the sanitary police; it was also connected with tavern life. ${ }^{1}$

An increase in venereal diseases among the conquerors and in the female population took place from about 1529, and more attention was paid to medical matters. From this date, lesions or symptoms which could have been due to syphilis, chancroid, lymphogranuloma venereum, gonorrhoea and other inflammatory urogenital disorders began to be reported. ${ }^{1}$

In 1534, the San Juan de Dios Hospital (also named "God's Love" or "Buboes") was founded by Friar Juan de Zumárraga. Only venereal diseases were treated at this institution, and it was supported by charity. Patients who had buboes or pus-filled ulcers were sent for treatment. Women who were not completely cured were moved to isolated prison cells, and were not permitted to return home. Obviously, medical attention was inadequate from all points of view but, fundamentally, because of a lack of the most elementary knowledge of the pathology of venereal diseases. The female indigenous population was the most vulnerable because from a very young age they experienced sexual relations, pregnancies, abortions and infections. ${ }^{12}$

In 1567, Pedro de Benavides published the first book (written in Mexico City and printed in Spain) on venereal diseases: Surgery Secrets. About Syphilis and Other Maladies. ${ }^{2}$ Problems with venereal diseases intensified in the seventeenth century, because of the arrival of a large number of immigrants who were highly promiscuous, lived in crowded conditions and did not practise good hygiene in relation to sexual intercourse. Reports which describe the venereal problems in New Spain show they were similar to those existing in Europe during this period. In 1776 a bando was proclaimed in Mexico City (the first of which we have. knowledge) on the functioning of "public houses" and surveillance of the women who worked in them, although specific activities were not mentioned. ${ }^{2}$

\section{THE NINETEENTH AND TWENTIETH \\ CENTURIES}

Almost a century later, during the French invasion of the $1860 \mathrm{~s}$, and at a time when the idea of reducing the danger of venereal diseases through simple inspection of women involved in prostitution had become established, the first formal regulation relating to this area was made. Sanitary inspection was introduced in conformity with the regulation. Emperor Maximiliano's government intended
Address for correspondence: Dr Carlos J Conde-Glez, Apartado Postal 222, Oficina de Correos 1, Mexico. 


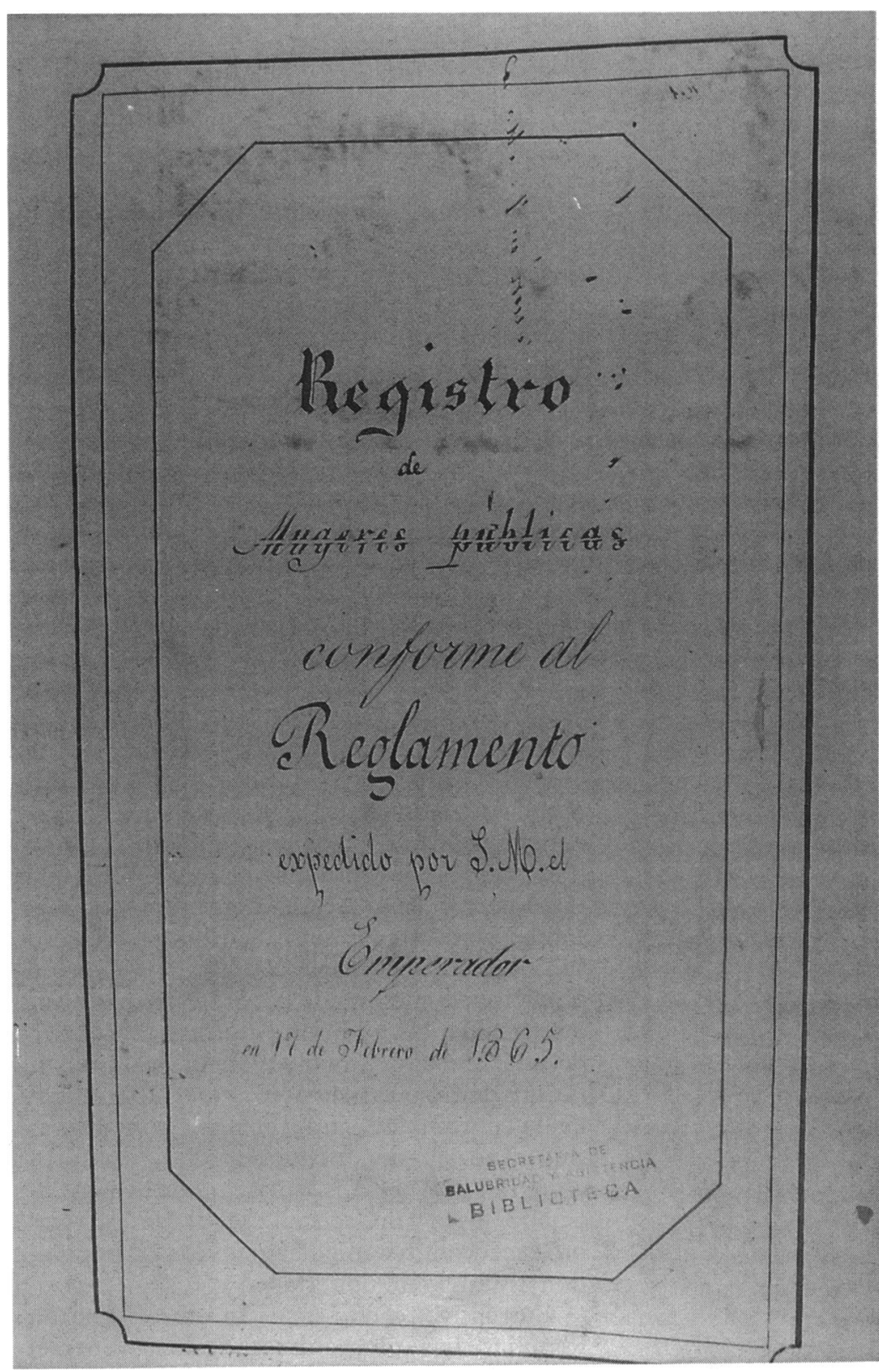

Figure 1 Front page of the prostitution registry established by order of Emperor Maximiliano, in Mexico City.

that this measure protect the health of the French, Austrian and Belgian soldiers who had participated in the invasion of Mexico. ${ }^{3}$

In his article on the history of health in Mexico, U. Valdés notes: "In the first registry of public women which, according to the new Sanity Inspection organisation, was begun this same year-1865-patent number one was allotted to Matiana Flores, who set up a house with ten women: nine Mexicans and one German". (figs 1,2$)$. The information collected in this registry shows that there were 563 commercial sex workers in Mexico City, $60 \%$ of whom were between 14 and 20 years of age; a third of the women was isolated at some time because of an unspecified urogenital infection. ${ }^{3}$

The Sanitary Inspection Commission presented a report about prostitution control on 31 December 1881. The chief inspector discussed deficiencies observed and suggestions as to how to improve services: "The system followed has converted Sanitary Inspection into an office where fines and quotas are paid by established houses and by workers, which is inappropriate as the law requires this to be a health office. We propose the following: 1. Improve the conditions at the office used by Sanitary Inspection; 2. Provide the office with three uterine mirrors and with desk supplies; 3. Provide all agents with complete supplies, even if this makes it necessary to reduce their number; 4. Keep a separate list of runaways and seek their efficient apprehension; and 5. Organise the work for the Inspection agents in such $a$ way that they are always active, and make the necessary reports about their aptitude and diligence". ${ }^{4}$

The literature produced in Mexico at the end of the nineteenth and the beginning of the twentieth centuries dealt mainly with moral and legal affairs regarding "public houses" and treatment and diagnosis available at the time for classical venereology. ${ }^{5-9}$

Wasserman's serological test for syphilis began to be used at the National Pathological Institute in $1910 .^{2}$ Later, on 31 July 1918, a commission nominated by the Higher Health Council produced a declaration which promoted syphilis prevention by the Public Health Department. Prevention was a fundamental aspect of the fight against venereal diseases during the Mexican Revolutionary period. In 1921 the first anti-venereal dispensary was established in Mexico City. Its activities were almost exclusively limited to weekly inspections of prostitutes; performing physical examinations, bacterioscopy and serology. Additional anti-venereal dispensaries were opened later, in Mexico City and in the outlying states, and this brought venereal diseases under the influence of the sanitary norms which are applied to all contagious diseases. ${ }^{10}$ ${ }^{11}$ Furthermore, laboratory tests became available and the first regular statistics appeared. (table 1)

In the years following these developments, the Department of Public Hygiene intensified the campaign against venereal diseases and extended it to the whole country. The

Table 1 Prevalence of classical venereal diseases in Mexico city*

\begin{tabular}{|c|c|c|c|c|c|}
\hline Year & $\begin{array}{l}\text { Gonorrhoea } \\
\times 100000 \text { pop } \\
\text { male cases }\end{array}$ & $\begin{array}{l}\text { Syphilis } \\
\times 100000 \text { pop } \\
\text { male cases }\end{array}$ & $\begin{array}{l}\text { Gonorrhoea } \\
\times 100000 \text { pop } \\
\text { female cases }\end{array}$ & $\begin{array}{l}\text { Syphilis } \\
\times 100000 \text { pop } \\
\text { female cases }\end{array}$ & $\begin{array}{l}\text { Chancroid } \\
\times 100000 \text { pop } \\
\text { female cases }\end{array}$ \\
\hline $\begin{array}{l}1921-1925 \\
1926-1928\end{array}$ & $\begin{array}{l}22952 \\
12162\end{array}$ & $\begin{array}{r}18819 \\
9919\end{array}$ & 896 & 2203 & - \\
\hline $\begin{array}{l}1926 \\
1927 \\
1928\end{array}$ & & & $\begin{array}{l}3138 \\
3092 \\
3620\end{array}$ & $\begin{array}{l}388 \\
305 \\
495\end{array}$ & $\begin{array}{l}1403 \\
1030 \\
1790\end{array}$ \\
\hline
\end{tabular}

* Data reported from seven dispensaries, each with two physicians, four nurses, two laboratory workers and four assistants. Treatments included thermal and electrical therapy, $\mathrm{K}_{2} \mathrm{MnO}$, irrigations and injections using sulphur and mercurial compounds. ${ }^{10}$ 


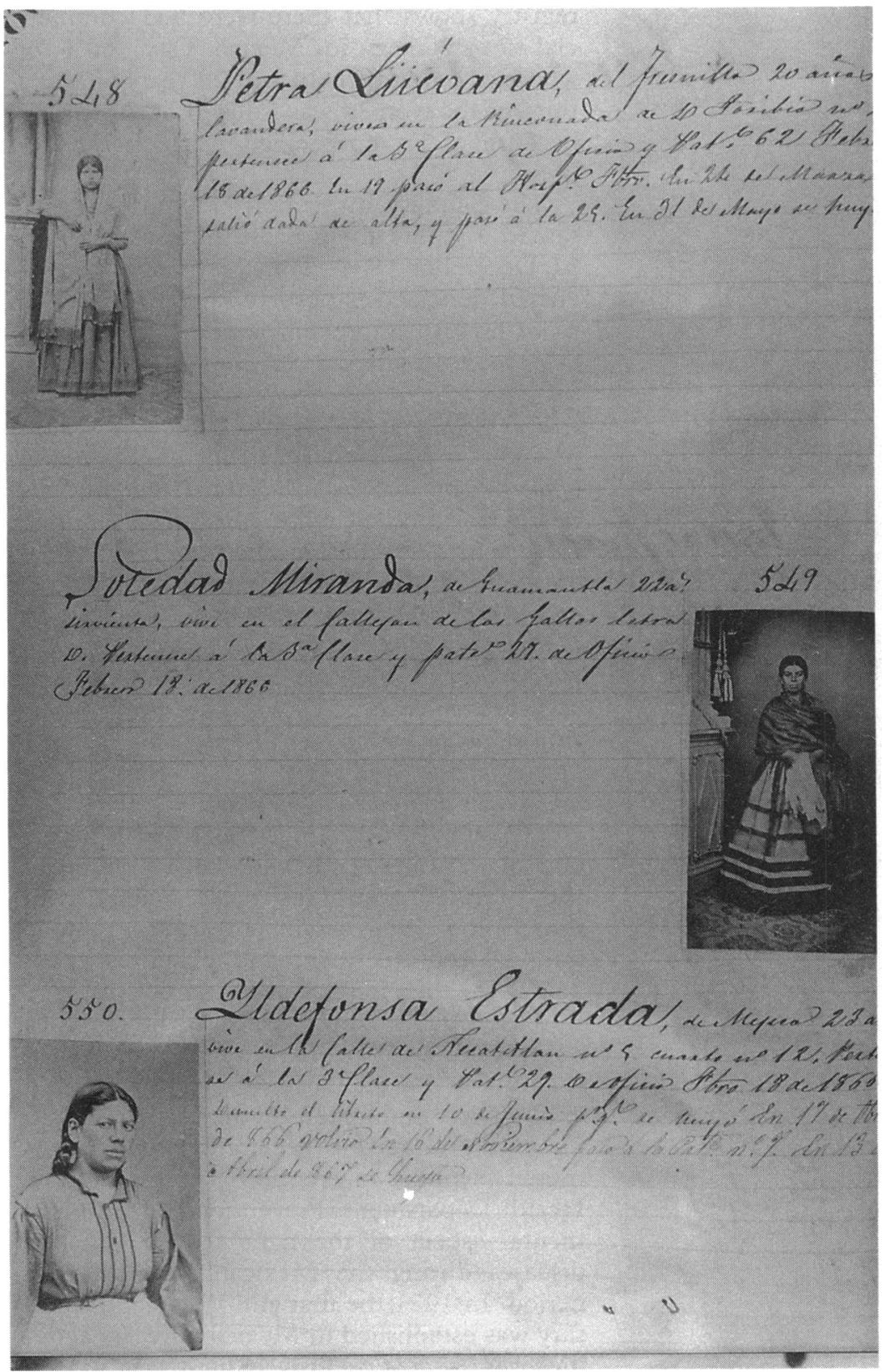

Figure 2 Pictures of prostitutes. Next to each picture there is the address, working place, age, place of birth, class and genital health status of the workers.

Department became interested in education, and organised conferences, film projections in theatres, cultural events in factories and schools and extensive distribution of printed information (which was carried out by brigades working throughout the country).$^{2}$

In 1926 a number of important developments took place, including the following: ${ }^{12} 13$

1. Premarital certificates (after a syphilis test) became obligatory, and prevention of ophthalmia neonatorum by use of $\mathrm{AgNO}_{3}$ promoted.

2. The Mexican Government abolished the regulation of prostitution, in accordance with League of Nations wishes. Fees were to be paid only by owners of establishments.

3. New regulations concerning prostitution were passed, and these can be considered the prologue to "abolitionism" (which would make venereal contagion illegal).

4. Intensive anti-venereal disease activities were undertaken.

In 1936, organised prevention efforts were begun, under the direction of the General Office of Epidemiology and Prevention of Contagious Diseases of the Ministry of Health. In 1940, the regulation on the practice of prostitution in Mexico City, dating from the French Intervention, was overturned. During the second six-year plan, from 1941 to 1946 , sanitary action by the federal government, state governments and municipalities was maintained. The control of prostitution by sanitary police was abandoned and the National Anti-Venereal Campaign Coordination established. ${ }^{13}$

In 1943, the use and distribution of penicillin were regulated by law, and the Dr. Eliseo Ramírez Centre was created. This functioned as a teaching centre, an anti-venereal dispensary and a reference laboratory. A first class institution, it was unfortunately closed down during the 1970s. In 1948, the anti-venereal campaign began to pursue independent plans and it received its own budget. $^{2}$

In 1952, the campaign became part of the General Directorate of Epidemiology and Sanitary Campaigns, with technical, standard-setting and executive functions. During the 1950 s and 1960 s the country's venereal disease problems became better known, personnel were trained and distribution of antivenereal information to the general population and medical professionals was intensified. In addition, during these two decades the efforts of a variety of health institutions and social services were more effectively coordinated, and tracing of contacts, as well as evaluation of laboratories, was promoted. The V.D.R.L. antigen, which is principally used in official laboratories, was produced, and serological surveys of population groups were undertaken. ${ }^{13} 14$

Currently, each state of the Mexican Republic has programmes against venereal diseases and information about their prevalence is available in the form of statistics and specific surveys (table 2). However, most of the programmes (except for syphilis and AIDS) rely on clinical diagnosis, as appropriate laboratory support is lacking.

Factors which may determine the prevalence of venereal diseases in Mexico include: urban concentration, industrialisation, a growing number of roads and highways which interconnect the country, internal migration, and tourism and business. Among the elements which contribute to sexual promiscuity (of basic importance in the propagation of these diseases), we can list the following: changing moral values, growth of women's emancipation, reduction of the restrictive influence of religion, family and public opinion, more frequent breakdown of the nuclear family, alcoholism, drug dependency, ignorance, and reliance on antibiotics and selfmedication. ${ }^{13} 1516$

Recent endeavours by the General Epidemiology Directorship and the National Institute of Public Health in Cuernavaca, Mexico (where a Laboratory and Epidemiology Program has operated since 
Table 2 Morbidity and mortality due to syphilis in Mexico*

\begin{tabular}{lllll}
\hline Year & Cases & $\begin{array}{l}\text { Rate } \\
(\times 100000 \text { pop })\end{array}$ & Deaths & $\begin{array}{l}\text { Rate } \\
(\times 100000 \text { pop })\end{array}$ \\
\hline 1945 & 40607 & 190.5 & Unknown & - \\
1950 & 29178 & $113 \cdot 1$ & 1897 & $6 \cdot 5$ \\
1955 & 23982 & $80 \cdot 8$ & 119 & $3 \cdot 5$ \\
1960 & 23817 & $68 \cdot 8$ & 678 & 1.9 \\
1970 & 10976 & $22 \cdot 4$ & 167 & $0 \cdot 4$ \\
1980 & 8774 & 13.5 & - & - \\
1990 & 2608 & $3 \cdot 2$ & - & - \\
\hline
\end{tabular}

Source: National Campaign against Veneral Diseases and the Epidemiology Directorship Health Ministry. (Gonorrhoea is reported at an annual average of 15000 cases, rate of $17 \cdot 5$ / 100000 ).

^Excluding congenital disease. gradually growing and $60 \%$ of the paediatric cases fell into this category in 1991. Transmission through blood transfusion has decreased and in 1991 accounted for $27 \%$ of the cases. Of accumulated paediatric cases, $48.7 \%$ result from perinatal transmission, $29.9 \%$ from transfusion, $19.6 \%$ in haemophiliacs and $1.8 \%$ from sexual abuse.

AIDS cases have been reported in all the states in Mexico, although the majority are located in large cities, and Mexico City accounts for $34 \cdot 2 \%$.

Clinical characteristics of AIDS in Mexico are different from those in developed countries. Eighty-eight percent of the cases have opportunistic infections different from $P$ carinii pneumonia, and of these tuberculosis is one of the most common, and is responsible for a significant number of AIDS deaths. Common manifestations in patients in the U.S. such as Kaposi's sarcoma are found relatively infrequently in Mexico. ${ }^{21}$

In 1986 the National Committee for AIDS Prevention was created in Mexico in order to monitor the course of this epidemic throughout the country and to establish criteria for diagnosis, treatment, prevention and control. In April of 1987, epidemiological surveillance started, and from that date case reporting has been obligatory. Since 1987 blood sales have been illegal; professional blood donation made up a third of the total blood transfused in the country at that time, and it was shown that paid blood donors were frequently infected with HIV. Testing for HIV antibodies in all blood units was made obligatory simultaneously, and a network of detection laboratories was established by the Ministry of Health. The network covers the entire country. In addition, an educational campaign was put into effect directed at the general population, homosexual men and prostitutes, with different strategies for each group but focused in general on condom use.

The AIDS epidemic in Mexico is the sum of various epidemics and the sexually transmitted AIDS epidemic has a different dynamic from that of AIDS transmitted through transfusions or perinatally. From the point of view of transmission there are three epidemics each of which has developed differently. However, the AIDS epidemic among men has different characteristics from that among women. Differences also exist according to geographical areas, and although currently AIDS is located principally in metropolitan areas, transmission in suburban areas is increasing and it therefore has a different dynamic. ${ }^{20}$

Mexico is among the 15 countries with the highest number of AIDS cases in the world, and the epidemic has an exponential rate of growth. There are different estimates of the current number of people infected with HIV. According to a model which takes into account diverse incubation periods, there is an average of 125000 people infected with the AIDS virus in Mexico, which on a gross estimation gives a prevalence of less than one person per thousand inhabitants, a level simi- 
lar to that found currently among blood donors in Mexico. ${ }^{20} 22$

Ten years after the beginning of the AIDS epidemic in Mexico, control systems have evolved and epidemiological approaches have changed. The principal challenge at present is to improve the living conditions of people infected with HIV and people with AIDS and, at the same time, make prevention and evaluation activities more effective.

The authors express their appreciation to librarian, Mrs Andre Lera, for providing valuable texts from the historical archive of our Institute's Library. We also thank Betania Allen for her support in preparing the English version of this paper.

1 Flores FA. Historia de la Medicina en México. Tomos I-III México. Secretaría de Fomento. 1888

2 Alvarez-Amézquita J, Bustamante ME, López-Picazos A Fernández del Castillo F. Historia de la Salubridad y de la Asistencia en México. Secretaria de Salubridad y Asistencia. 1960.

3 Anonymous. Registro de Mujeres Públicas. México. Anonymous. 1865.

4 Huici J. Prostitución. Informe de la inspección de sanidad. Boletin del Consejo Superior de Salubridad. 1881;1:73-78.

5 Bernal M. Tratamiento de la blenorragia crónica. In. Liceaga E. (ed). Memorias del Segundo Congreso Médico Mexicano. México. Secretaría de Fomento. 1897:74-75.

6 Pagenstecher F. La gonorrea crónica en la mujer y su diagnóstico retrospectivo. In: Liceaga E. (ed). Memoria del Segundo Congreso Médico Mexicano. México. Secretaría de Fomento. 1897: 238-244.

7 Sánchez y Muñoz F. Tratamiento de la sífilis por el método de Althaus. In: Liceaga E. (ed). Memorias del Segundo Fomento. 1897: 76-8.

8 Effertz 0 . Algunas observaciones sobre la terapia de la gonorrea y la termoterapia en general. Boletín del Consejo
Superior de Salubridad. 1901;VII:47-53.

9 Wolff R. Supresión o conservación de las casas de toleran cia. Boletin del Consejo Superior de Salubridad. 1901;VI: $20-8$.

10 Anonymous. Memorias de los trabajos realizados por el Departamento de Salubridad Pública 1925-1928. México. Departamento de Salubridad Pública. 1928.

11 Anonymous. Boletín mensual de enfermedades transmisibles. Num 1. México. Departamento de Salubridad Pública. Num 1.

12 Anonymous. Reglamento para el ejercicio de la prostitución. Boletin del Departamento de Salubridad Pública. 1926;2:163-85.

13 González-Galván E. Las enfermedades venéreas en México. Prensa Médica Mexicana. 1974;XXXIX 389-93.

14 Anonymous. Memoria de la Secretaria de Salubridad Asistencia Pública. Sexenio 1952-1958. México. SSA. 1958.

15 Sepúlveda-Amor J. SIDA, ciencia y sociedad en México. México. Biblioteca de la Salud. 1989.

16 Calderón JE, Conde GC, Echániz AG. Enfermedades adquiridas por contacto sexual. Prioridades en México. Rev Inst Nal Enf Resp Mex. 1990;3:69-72.

17 Conde-Glez CJ, Calderón E, Náder E, Mondragón VA. A three year survey of Neisseria gonorrhoeae in Mexico. In Achtman M, Kohl P, Marchal C, et al. (eds) Neisseriae 1990. Berlin. Walter de Gruyter. 1991:31-35.

18 Echániz-Avilés G, Calderón-Jaimes E, Carnalla-Barajas N. Prevalencia de infección cervicovaginal por Chlamydia trachomatis en población femenina de la ciudad de Cuernavaca, Morelos. Salud Pública de México. 1992; 34:301-7.

19 Juárez-Figueroa $\mathrm{L}$ Uribe $\mathrm{F}$, Hernández $\mathrm{P}$, et al. Prevalence and determinants of HIV and other STDs in a population of female commercial sex workers in a population of female commercial sex workers in Mexico City.

20 Valdespino JL, García ML, Del Río A, et al Epidemiología del SIDA en México en 1991. Logros y nuevos retos. Boletin SIDA/ETS. 1991;5:2054-6.

21 Magis CL García GL, González MG, Valdespino JL Sepúlveda J. Aspectos clínicos de los casos de SIDA en México al momento de la notificación. Boletín SIDA/ETS. 1992;6:2094.

22 Herrera-Ortíz F, Juárez-Figueroa L. Prevalence of antibody to HIV-1 in Mexican blood donors. Sixth International Conference on AIDS. 1990:FC593. 